\title{
Heat production in Littorina saxatilis Olivi and Littorina neritoides L. (Gastropoda: Prosobranchia) during an experimental exposure to air
}

\author{
Inge Kronberg \\ Zoologisches Institut der Christian-Albrechts-Universität, Abt. Marine Ökologie und \\ Systematik; Olshausenstraße 40-60, D-2300 Kiel, Federal Republic of Germany
}

\begin{abstract}
The adaptation of littorinid molluscs to prolonged aerial exposure was investigated by the determination of heat production. Littorina saxatilis, inhabiting the upper eulittoral, reached a maximum metabolic activity during submersion (heat production: $3.26 \times 10^{-3} \mathrm{~J} \mathrm{~s}^{-1}\left(\mathrm{~g}_{\mathrm{adw}}\right)^{-1}$. On the first three days of desiccation, the heat production was continuously reduced to $40 \%$ of the submersed value. A prolonged aerial exposure was lethal for this species. In the supralittoral $L$. neritoides, three stages of energy metabolism could be observed: an intermediate heat production during submersion $\left(1.97 \times 10^{-3} \mathrm{~J} \mathrm{~s}^{-1}\left(\mathrm{~g}_{a d w}\right)^{-1}\right)$, an increased metabolism during the first hour of aerial exposure (heat production $204 \%$ of submersed value), and a minimal metabolism ( $39 \%$ of the submersed value and $19 \%$ of maximum value) during the following days and weeks of desiccation. Recovery depended on water salinity; $L$. saxatilis proved to be less euryhaline than $L$. neritoides. Thus, the metabolic adaptations correlate with the level of littoral habitat; inactivity combined with a drastically reduced energy consumption is a metabolically economic way to survive in periodically dry environments.
\end{abstract}

\section{INTRODUCTION}

Littorinid snails are characteristic molluscan inhabitants of rocky shores worldwide and mark the upper limit of marine influence. They live in a habitat of unpredictable change in moisture, salinity and temperature (Kronberg, 1988).

These special living conditions have made them a favourite subject of numerous ecophysiological investigations (see Pettitt, 1974 for a bibliography) concerning their reproduction (Berry, 1961; Behrens, 1972; Berger, 1975; Fretter \& Manly, 1977; Clyne \& Duffus, 1979; Schmitt, 1979; Fretter, 1980; Hughes \& Roberts, 1980), excretion (Daguzan, 1975) and salinity tolerance (Broekhuysen, 1940; Mayes, 1962; Todd, 1964; Remmert, 1968; Berger, 1978; Berger \& Kuz'min, 1978). The first investigations of energetic adaptations were carried out by Sandison (1966), Vermeij (1973), Pamatmat (1978) and Newell (1979).

An important predisposition of littorinids for the periodically dry environment lies in their ability to reduce waterloss by tightly closing their shell with an operculum. In the retracted state they are able to withstand days or even months of exposure to air (Fraenkel, 1961), but there are consequences to this drastic reaction: ingestion, excretion and defecation are interrupted and gas-exchange is disturbed. The $\mathrm{O}_{2}$ reserve in the 
mantle cavity is limited, so that after a while the animal has to live in a sub- or anoxic milieu.

The aerobic-anaerobic change in metabolism of littoral animals does not necessarily correspond to a submersion-emersion change on the shore: during exposure to air the aerobiosis can be maintained for some time, while on the other hand anaerobiosis during submersion has been observed; both pathways may even work in parallel (de Zwaan, 1977).

The appropriate method to estimate the metabolic activity of quiescent littorinids is to record the heat production, which includes the aerobic and anaerobic part of metabolism. Differences in metabolic reactions may explain specific zonation patterns of littorinids on rocky shores, in this case the upper eulittoral Littorina saxatilis Olivi ( $L$. rudis sensu Heller, 1975) and the supralittoral $L$. neritoides L.

\section{MATERIALS AND METHODS}

1000 individuals of Littorina saxatilis (live weight $0.04-0.08 \mathrm{~g} / \mathrm{Ind}$.) were collected in September 1981 from the upper eulittoral in Bülk (salinity of source $15 \%$, Kiel Bight, Baltic Sea) and 1000 individuals of $L$. neritoides (live weight $0.04-0.11 \mathrm{~g} / \mathrm{Ind}$.) came from the supralittoral in Alta Fulla (salinity of source 36\%, Mediterranean, Spain, September 1981).

The snails were kept in basins with plaster-of-paris saturated with artificial seawater (salinity of source, temperature $20^{\circ} \mathrm{C}$, air humidity $65-75 \%, 16 \mathrm{~h}-8 \mathrm{~h}$ light-dark rhythm). Each basin contained 80 to 150 individuals.

\section{Aerial exposure}

Heat production, biomass and mortality were determined after half an hour $(1 / 2 \mathrm{~h})$, one day ( $1 \mathrm{~d})$, three days ( $3 \mathrm{~d})$, one week ( $1 \mathrm{w})$, two weeks $(2 \mathrm{w})$ and four weeks $(4 \mathrm{w})$ of aerial exposure. Heat production measurements were carried out with a LKB-batch calorimeter (Type LKB 1070) at a temperature of $14^{\circ} \mathrm{C}$. Baseline stability was tested previously in a 1 to 2 hour run. A detailed description of the calorimeter is given by Bengtsson (1982). Three measurements, each containing 4 snails, guaranteed an accuracy of $\pm 0.35 \times 10^{-3} \mathrm{~J} \mathrm{~s}^{-1}\left(\mathrm{~g}_{\mathrm{adw}}\right)^{-1}$ (Kronberg, 1983). Measurements were carried out over a one to two hour-period including 15-20 min equilibration time. The steel chamber capacity of $4 \mathrm{ml}$ did not limit the aerobic metabolism of the 4 snails during the experiment (Sandison, 1966; Kronberg, 1983). Following the experimental series, live weight (including shell), dry weight ( 8 days dried at $\left.80^{\circ} \mathrm{C}\right)$ and ashfree dry weight (adw) $(4 \mathrm{~h}$ ashed at $500^{\circ} \mathrm{C}$ ) were determined; ashfree live weight was used to estimate the tissue weight.

For the determination of mortality rate, 80 to 150 separate individuals were moistened with seawater after a given desiccation time $(3 \mathrm{~d}, 1 \mathrm{w}, 2 \mathrm{w}, 4 \mathrm{w})$ and the number of animals which did not show their tentacles within 5 minutes was counted (Broekhuysen, 1940).

Following Fraenkel (1961) who mentioned a tolerance of several months in littorinids, an experimental desiccation time of four weeks was decided on. For $L$. saxatilis this period proved too long, as all individuals died within four weeks. 


\section{Aquatic recovery}

After a one-week exposure to air the snails were reimmersed in water (salinity of source), one hour later heat production was measured. The equilibration time of the steel chambers in the calorimeter is too long to show the immediate answer to submersion. The snails were not fed prior to measurements being taken.

In separate groups of snails the reaction to water of different salinity was tested. For each salinity $(0,10,15,20,25,30,35,40,50,60 \%) 20$ individuals were moistened after $1 \mathrm{~h}, 3 \mathrm{~d}, 2 \mathrm{w}$ of aerial exposure, and the number of individuals showing tentacles after 5 minutes was counted. Survival of the remaining snails was tested by exposure to water with salinity of source.

\section{RESULTS}

\section{Aerial exposure}

The percentage of surviving snails is given in Figure 1 . In both species, $95 \%$ survived the first three days of exposure to air. $91 \%$ of Littorina neritoides stayed alive throughout the experimental duration of four weeks; but in $L$. saxatilis only $21.9 \%$ survived 2 weeks of aerial exposure, and none lasted 4 weeks.

The weight loss of $L$. saxatilis (10-12\%) after one week of desiccation was two times higher than that in L. neritoides (3-6\%) (Fig. 1).

Figure 2 illustrates the changes in heat production during desiccation of the two species. The sign + indicates the level of significance (U-test, $\alpha=0.05$ ). In $L$. saxatilis, heat production reached its maximum under water: $3.26 \times 10^{-3} \mathrm{~J} \mathrm{~s}^{-1}\left(g_{\text {adw }}\right)^{-1}$. During exposure to air it fell by degrees; thus, a significant change $(+)$ compared to the submersed situation manifested itself only after three days $\left(1.35 \times 10^{-3} \mathrm{~J} \mathrm{~s}^{-1}\left(\mathrm{~g}_{\text {adw }}\right)^{-1}\right)$. After 1 week of aerial exposure, an increase could be observed.

Under submersed conditions the heat production of $L$. neritoides $\left(1.97 \times 10^{-3} \mathrm{~J}\right.$ $\left.\mathrm{s}^{-1}\left(\mathrm{~g}_{\mathrm{adw}}\right)^{-1}\right)$ reached only two thirds of the value of the eulittoral species. Within half an hour of aerial exposure, the heat production of $L$. neritoides doubled $\left(4.03 \times 10^{-3} \mathrm{~J}\right.$ $\left.\mathrm{s}^{-1}\left(\mathrm{~g}_{\mathrm{adw}}\right)^{-1}\right)(+)$. Next day it dropped again $(+)$ below the submersed value and yielded $0.98 \times 10^{-3} \mathrm{~J} \mathrm{~s}^{-1}\left(\mathrm{~g}_{\mathrm{adw}}\right)^{-1}$. During the following weeks of the experiment the heat production remained more or less unchanged i.e. between 1.17 and $0.76 \times 10^{-3} \mathrm{~J} \mathrm{~s}^{-1}\left(g_{\text {adw }}\right)^{-1}$.

\section{Aquatic recovery}

Heat production one hour after aquatic recovery in seawater of source salinity (following 1 week desiccation) did not differ significantly from that before recovery:

L. saxatilis: $2.39 \times 10^{-3} \mathrm{~J} \mathrm{~s}^{-1}\left(\mathrm{~g}_{\mathrm{adw}}\right)^{-1}$

$$
\text { (before recovery: } 2.55 \times 10^{-3} \mathrm{~J} \mathrm{~s}^{-1}\left(\mathrm{~g}_{\mathrm{adw}}\right)^{-1}
$$

L. neritoides: $1.21 \times 10^{-3} \mathrm{~J} \mathrm{~s}^{-1}\left(\mathrm{~g}_{\mathrm{adw}}\right)^{-1}$

$$
\text { (before recovery: } 1.03 \times 10^{-3} \mathrm{~J} \mathrm{~s}^{-1}\left(\mathrm{gadw}_{\mathrm{adw}}\right)^{-1}
$$

The recovery of the littorinids depended on the salinity of water used for reimmersion (Fig. 3). Most snails regained their activity, when the salinity of the water was slightly higher than that of their natural environment. L. saxatilis tolerated salinities in the range 

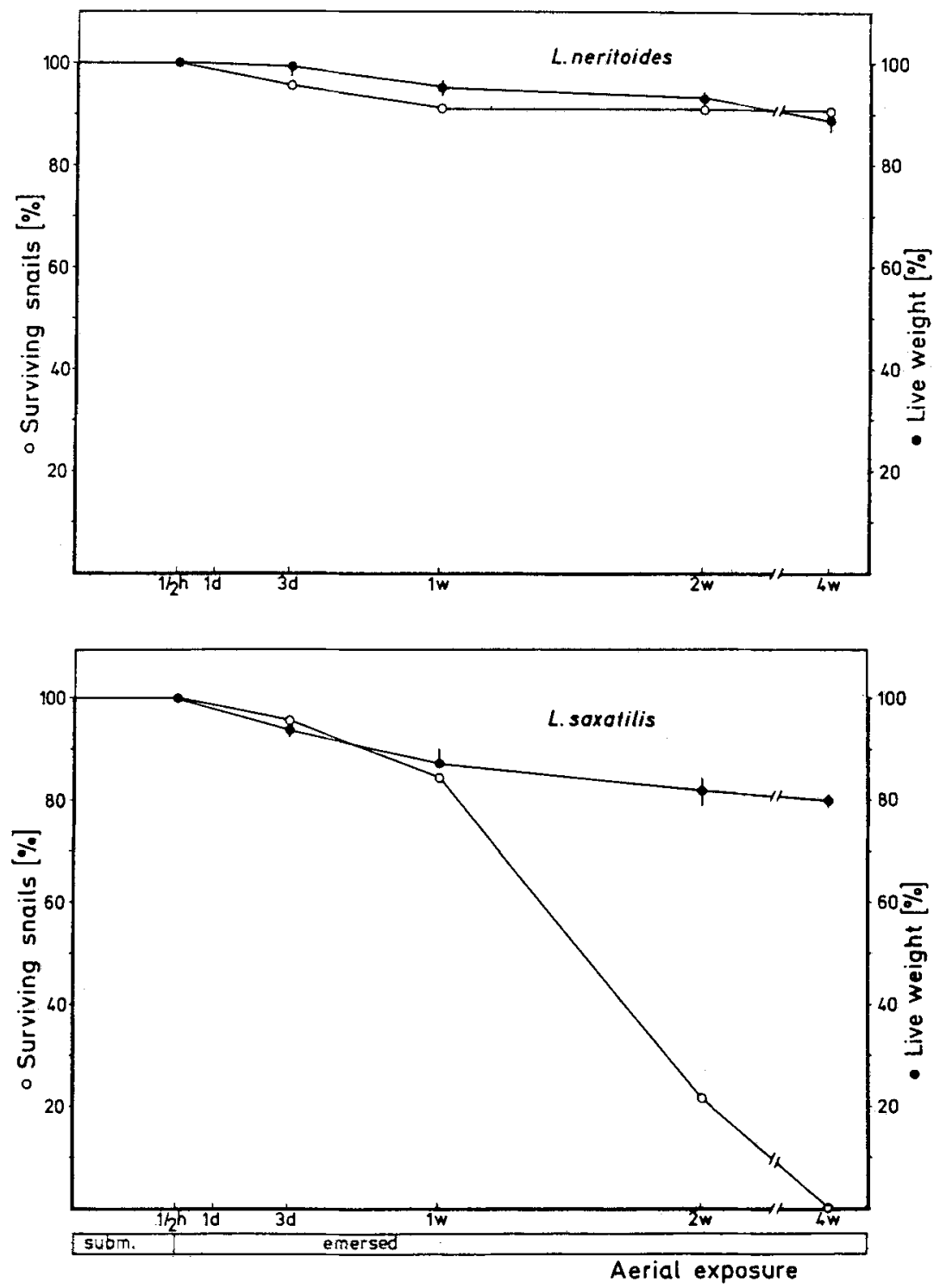

Fig. 1. Mortality $(O)$ and weight loss $(\bullet)$ in $L$. neritoides and $L$. saxatilis. Bar $=$ standard error 

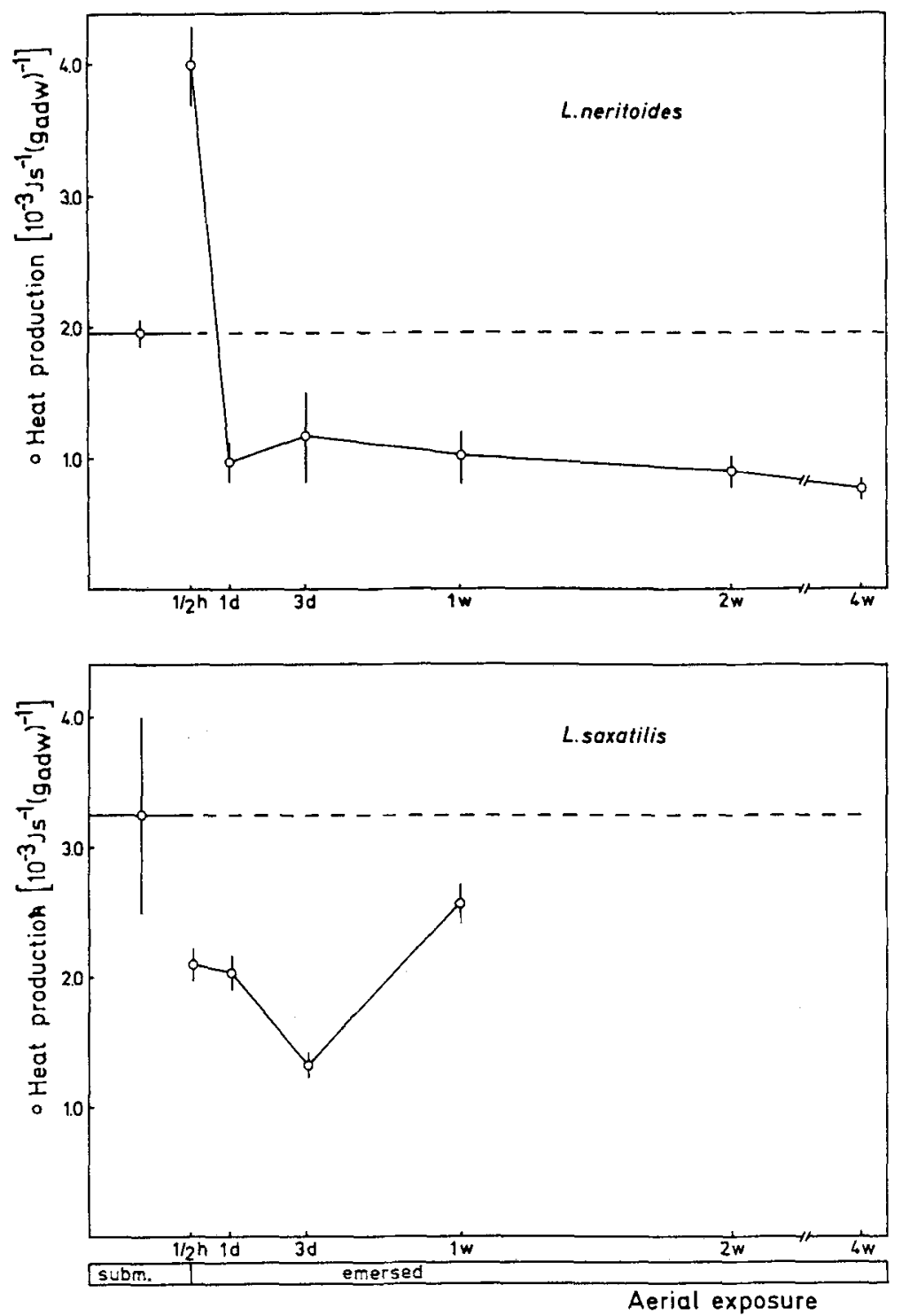

Fig. 2. Heat production in $L$. neritoides and $L$. saxatilis during aerial exposure. Bar $=$ standard error 

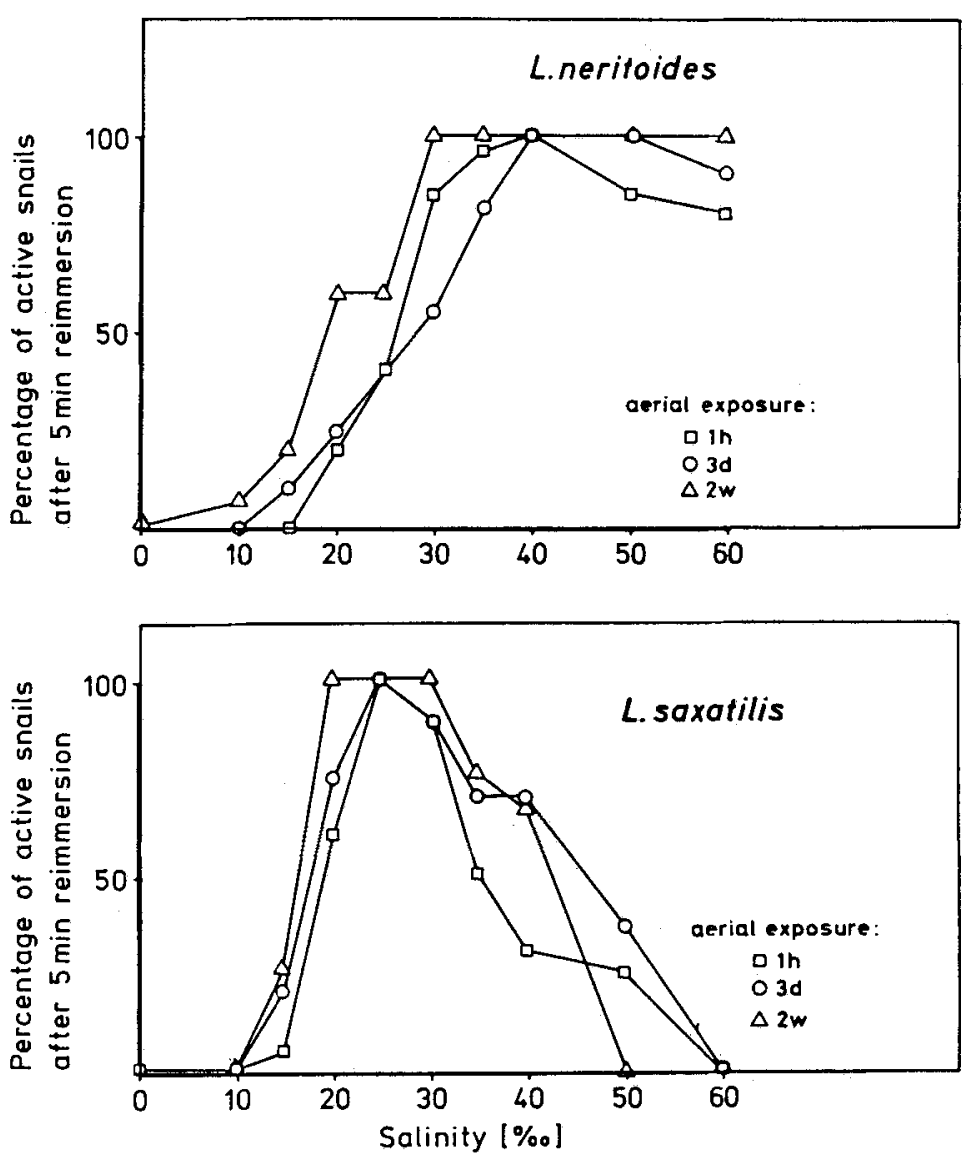

Fig. 3. Recovery of $L$. neritoides and $L$. saxatilis after increasing duration of aerial exposure in artificial seawater of different salinity

of $15-50 \%$, but best recovery was between 20 and $35 \%$. Corresponding figures for $L$. neritoides were $15-60 \%$, with optimal recovery in seawater $>30 \%$.

In both snails there was a tendency to accept a wider range of salinities if the preceding desiccation was longer, but statistical significance was not achieved.

\section{DISCUSSION}

Littoral environments are characterized by a periodical change of emersion and submersion, which affects the energy metabolism of the inhabitants, as shown in Mytilus and Cardium (Widdows \& Shick, 1985; Shick et al., 1986). The balance between aerial and aquatic respiration shows a dependence on the littoral zonation of the habitat. Table 1 shows heat production in different littoral animals. 
Table 1. Heat production in different littoral animals $\left(\mathrm{J} \mathrm{s}^{-1}\left(\mathrm{~g}_{\text {tissue }}\right)^{-1}\right)$. Averaged values from the whole desiccation series, related to ashfree live weight (approximately tissue weight)

\begin{tabular}{|c|c|c|}
\hline Species & Heat production & Reference \\
\hline \multicolumn{3}{|l|}{ Gastropoda } \\
\hline Littorina neritoides & $0.31^{*}$ & present study \\
\hline L. saxatilis & $0.47^{*}$ & present study \\
\hline L. littorea & 0.45 & Hammen (1979) \\
\hline \multicolumn{3}{|l|}{ Bivalvia } \\
\hline Mytilus edulis & 0.44 & Hammen (1979) \\
\hline Mercenaria mercenaria & 0.86 & Hammen (1979) \\
\hline Mya arenaria & 0.53 & Hammen (1979) \\
\hline Crassostrea angulata & 1.73 & Hammen (1979) \\
\hline \multicolumn{3}{|l|}{ Anthozoa } \\
\hline $\begin{array}{l}\text { Actinia equina } \\
\text { (under aerial exposure) }\end{array}$ & 1.29 & Shick (1981) \\
\hline \multicolumn{3}{|l|}{ Crustacea } \\
\hline Libinia dubia & 0.34 & Hammen (1979) \\
\hline
\end{tabular}

The heat production of the observed snails Littorina saxatilis and L. neritoides lies in the lower range of the values measured in other littoral animals (Hammen, 1979; Shick, 1981).

$L$. saxatilis and $L$. neritoides are inhabitants of the upper eulittoral and supralittoral, respectively, and, therefore, are exposed to different periods of natural desiccation.

The upper eulittoral is frequently exposed to air for several hours, but exposure times of more than one day occur only occasionally. In the supralittoral, on the other hand, aerial exposure of more than one week is common. In both species the gills are well developed and growth is positively allometric - so that there is no difference between the gill sizes of $L$. saxatilis and $L$. neritoides individuals of equal weight (Remmert, 1968). The mantle cavity of $L$. neritoides is more vascularized and, therefore, these snails are better adapted to air breathing than L. saxatilis (Remmert, 1968). Under conditions of high humidity the snails are able to maintain aerobiosis for a long time (Newell, 1973). In the littoral they graze and aggregate in small crevices. L. neritoides is able to move on dry surfaces while $L$. saxatilis stops activity as soon as there is no moisture outside the shell. Quiescence during intertidal exposure not only reduces water loss but also conserves energy, the diminished energy demand often being met by anoxibiosis (Shick et al., 1988). Patanè $(1946,1955)$ has shown that $L$. neritoides and $L$. punctata are able to survive in pure nitrogen for some days. Anaerobiosis is detectable by the analysis of end products: Wieser (1980) found an accumulation of alanine in L. littorea kept in nitrogen or air. In L. saxatilis, McManus \& James (1975) determined the proportion of alanine: succinate:lactate as $2: 1: 1$.

Heat production includes both the aerobic and anaerobic parts of metabolism. Maximum activity of the snails is shown by maximum heat production: in $L$. saxatilis during submersion $\left(3.26 \times 10^{-3} \mathrm{~J} \mathrm{~s}^{-1}\left(\mathrm{~g}_{\mathrm{adw}}\right)^{-1}\right)$ and in L. neritoides $\left(4.03 \times 10^{-3} \mathrm{~J} \mathrm{~s}^{-1}\left(\mathrm{~g}_{\mathrm{adw}}\right)^{-1}\right)$ after short emersion and under humid conditions. At this time $(1 / 2 \mathrm{~h})$ of experiment, 
locomotion in $L$. saxatilis had ceased and the animal had closed the operculum to reduce water loss. In $L$. neritoides continuous desiccation of 1 to 3 days was required before the operculum was closed and all locomotion stopped as it did in L. saxatilis. The energy demand diminishes because energy-utilizing processes like muscle activity are drastically reduced. In $L$. saxatilis the heat production after $1 / 2 h, 1$ and 3 days of desiccation was 65 to $40 \%$ of the submersed values; in $L$. neritoides the heat production first doubled and then fell under the level of the submersed value after one day of desiccation. It then remained more or less constant until the end of the experiment (around $1.0 \times 10^{-3} \mathrm{~J}$ $\left.\mathrm{s}^{-1}\left(\mathrm{~g}_{\mathrm{adw}}\right)^{-1}\right)$.

For $L$. saxatilis, desiccation of more than one week does not represent the natural condition. After this length of time the snails had reached their limit, as $78.1 \%$ of the control animals died after 2 weeks (Fig. 1) and evaporative water loss had reached $20 \%$.

Exposure to air for more than one week, however, is a common situation for $L$. neritoides. The thick shell and the operculum protect them from evaporation, so that weight loss over a 4 -week period amounts to only about $10 \%$. As shown by the measurement of heat production, metabolism is minimized and nearly all animals survive the experimental period of 4 weeks. Consequently, the zonation patterns of the two littorinids in the littoral habitat are well illustrated by the metabolic differences of the two species.

Desiccated snails are hygroscopic, small drops of water put on the operculum being absorbed even by dead snails by a purely physical process. Whenever living snails were moistened with seawater after exposure to air, they opened the operculum, tested quality of the water, and restarted their locomotory activity if the salinity was suitable (Fig. 3). In littoral crevices, water salinity is not only determined by surface water, but also by evaporation, rain and dew - the snails can recover under a wide range of different salinities from freshwater to high salinity concentrations. After a long period of drought, even the rain that falls on a rocky shore becomes salty, as it dissolves crystallized salt layers. It is, therefore, not surprising that $L$. saxatilis and $L$. neritoides prefer higher salinities than the salinity of the surface water of the source. $L$. saxatilis appears to be less euryhaline than $L$. neritoides.

One hour after recovery with water (salinity of source), the heat production values did not differ significantly from those before recovery. This might be due to starvation, as the animals were not fed in the chamber of the calorimeter, for fear that the heat production of algae, introduced for food, might disturb the measurements.

The metabolic changes in the observed periwinkles obviously concur with the emersion times they are accustomed to on the shore. The special adaptation of $L$. neritoides to high shore levels is not only due to protection by the thick shell but also due to important physiological adaptations in the metabolism. Littorinids should be called "euryoxic" (Hammen 1976). The ability to change metabolic pathways is an important adaptation to the unpredictable conditions of the environment. The cessation of several life functions enables the littorinids to survive on dry shores but inhibits the step to a real terrestrial life.

Acknowledgements. Thanks are due to Dr. R. Pulz and Dr. G. Graf (Kiel SFB 95) for their cooperation and for the use of their facilities, to Prof. Dr. J. M. Shick for helpful criticism and to Prof. Dr. V.B. Meyer-Rochow (New-Zealand) for prereviewing the manuscript. 


\section{LITERATURE CITED}

Behrens, S., 1972. The role of wave impact and desiccation in the distribution of Littorina sitkana (Philippi). - Veliger 15, 129-132.

Bengtsson, W., 1982. Aktivität des Elektronen-Transport-Systems (ETS) und Wärmeproduktion mariner Sedimente. Diss., Univ. Kiel, 116 pp.

Berger, V. Y., 1975. The changes of euryhalinity in ontogenesis and adaptations connected with reproduction of the White Sea mollusc Littorina saxatilis. - Biol. Morja, Vladiv. 1, 43-50.

Berger, V. Y., 1978. A study of salinity adaptations of the mollusk Littorina sitchana with relation to ideas on the evolution of the genus Littorina. - Zool. Zh. 57, 1786-1789.

Berger, V. Y. \& Kuz'min, A. N., 1978. Effect of low salinity on the development of some White Sea mollusks. - Zool. Zh. 57, 1632-1636.

Berry, A. J., 1961. Some factors affecting the distribution of Littorina saxatilis (Olivi). - J. Anim. Ecol. $30,27-45$.

Broekhuysen, G. J., 1940. A preliminary investigation of the importance of desiccation, temperature and salinity as factors controlling the vertical distribution of certain intertidal marine gastropods in False Bay, South Africa, - Trans. R. Soc. S. Afr. 28, 255-292.

Clyne, P. M. \& Duffus, J. H., 1979. A preliminary study of variation in reproduction of Littorina rudis. - J. moll. Stud. 45, 178-185.

Daguzan, J., 1975. Recherches sur les Littorinidae. Thèse, Univ. Rennes, 189 pp.

Fraenkel, G., 1961. Resistance to high temperatures in a Mediterranean snail, $L$. neritoides. Ecology 42, 604-606.

Fretter, V., 1980. Gross anatomy of the female genital duct of British U.K. Littorina spp. - J. moll. Stud. $46,148-153$.

Fretter, V. \& Manly, R., 1977. The settlement and early benthic life of Littorina neritoides (L.) at Wembury, S. Devon (England). - J. moll. Stud. 43, 255-262.

Hammen, C. S., 1976. Respiratory adaptations: Invertebrates. In: Estuarine processes. Ed. by M. Wiley. Acad. Press, New York, 1, 347-355.

Hammen, C. S., 1979. Metabolic rates of marine bivalve molluscs determined by calorimetry. Comp. Biochem. Physiol. 62 (A), 955-969.

Heller, J., 1975. The taxonomy of sorne British Littorina species' with notes on their reproduction (Mollusca: Prosobranchia). - Zool. J. Linn. Soc. 56, 131-151.

Hughes, R. N. \& Roberts, D. J., 1980. Reproductive effort of winkles (Littorina spp.) with contrasted methods of reproduction. - Oecologia 47, 130-136.

Kronberg, I., 1983. Ökologie der Schwarzen Zone im marinen Felslitoral: Monographie eines extremen Lebensraumes. Diss., Univ. Kiel, 237 pp.

Kronberg, I., 1988. Structure and adaptation of the fauna in the black zone (littoral fringe) along rocky shores in northern Europe. - Mar. Ecol. Prog. Ser. 49, 95-106.

Mayes, P. A., 1962. Comparative investigations of the euryhaline character of Littorina and the possible relationship to intertidal zonation. - Nature, Lond. 195, 1269-1270.

McManus, D. P. \& James, B. L., 1975. Anaerobic glucose metabolism in the digestive gland of Littorina saxatilis rudis (Maton) and in the daughter sporocysts of Microphallus similis (Jäg) (Digenea: Microphallidae). - Comp. Biochem. Physiol. 51 (B), 293-297.

Newell, R. C., 1973. Factors affecting the respiration of intertidal invertebrates. - Am. Zool. 13, 513-528.

Newell, R. C., 1979. Biology of intertidal animals. Marine ecological surveys LTD., Faversham, Kent, $781 \mathrm{pp}$.

Pamatmat, M. M., 1978. Oxygen uptake and heat production in a metabolic conformer (Littorina irrorata) and a metabolic regulator (Uca pugnax). - Mar. Biol. 48, 317-325.

Patanè, L., 1946. Anaerobiosì in Littorina neritoides (L.). - Boll. Soc. ital. Biol. sper. 21, 928-929.

Patanè, L., 1955. Cinesi i tropismi, anidro-e anaerobiosi in Littorina neritoides (L.). - Boll. Sed. Accad. gioenia Sci. nat. 3, 65-73.

Pettitt, C. W., 1974. An indexed bibliography of the family Littorinidae (Gastropoda, Mollusca) 1758-1973. Manchester Museum, The Univ., Manchester, 36 pp.

Remmert, H., 1968. Die Littorina-Arten: Kein Modell für die Entstehung der Landschnecken? Oecologia 2, 47-54. 
Sandison, E. E., 1966. The oxygen consumption of some intertidal gastropods in relation to zonation. - J. Zool., Lond. 149, 163-173.

Schmitt, R. J., 1979. Mechanics and timing of egg capsule release by the littoral fringe periwinkle Littorina planaxis (Gastropoda: Prosobranchia), - Mar. Biol. 50, 359-366.

Shick, M., 1981. Heat production and oxygen uptake in intertidal sea anemones from different shore heights during exposure to air. - Mar. Biol. Lett. 2, 225-236.

Shick, J. M., Gnaiger, E., Widdows, J., Bayne, B. L. \& Zwaan, A. de, 1986. Activity and metabolism in the mussel Mytilus edulis L. during intertidal hypoxia and aerobic recovery. - Physiol. Zool. 59, $627-642$.

Shick, J. M., Widdows, J. \& Gnaiger, E., 1988. Calorimetric studies of behavior, metabolism and energetics of sessile intertidal animals. - Am. Zool. 28, 161-181.

Todd, M. E., 1964. Osmotic balance in Littorina littorea, L. littoralis and L. saxatilis. - Physiol. Zool. $37,33-34$.

Vermeij, G. J., 1973. Morphological patterns in high intertidal gastropods: Adaptive strategies and their limitations. - Mar. Biol. 20, 319-346.

Widdows, J. \& Shick, J. M., 1985. Physiological responses of Mytilus edulis and Cardium edule to aerial exposure. - Mar. Biol. 85, 217-232.

Wieser, W., 1980. Metabolic end products in 3 species of marine gastropods. - J. mar. biol. Ass. U.K. $60,175-180$.

Zwaan, A. de, 1977. Anaerobic energy metabolism in bivalve molluscs. - Oceanogr. mar. Biol. 15, 102-187. 